\title{
Merging the arts and sciences for collaborative sustainability action: a methodological framework
}

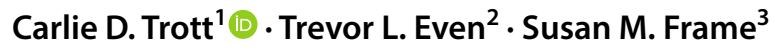

Received: 2 July 2019 / Accepted: 16 March 2020 / Published online: 2 April 2020

(c) The Author(s) 2020

\begin{abstract}
This manuscript explores the possibilities and challenges of art-science integration in facilitating collaborative sustainability action in local settings. To date, much sustainability education is prescriptive, rather than participatory, and most integrated art-science programming aims for content learning, rather than societal change. What this means is that learners are more often taught "what is" than invited to imagine "what if?" In order to envision and enact sustainable alternatives, there is a need for methods that allow community members, especially young people, to critically engage with the present, imagine a better future, and collaboratively act for sustainability today. This manuscript introduces a methodological framework that integrates the arts and sciences to facilitate: (1) transdisciplinary learning, focusing on local sustainability challenges; (2) participatory process, bringing experience-based knowledge into conversation with research-based knowledge; and (3) collaborative sustainability action, inviting community members to envision and enact sustainable alternatives where they live. The transformative potential of this framework is examined through international case studies from countries representing the richest and poorest in the Western hemisphere: a multi-site research study and after-school program for climate change education and action in collaboration with children in the Western US; and a multi-cycle research study and community arts center course for environmental photography and youth-led water advocacy in Southern Haiti. Despite many shared characteristics, case studies diverge in important ways relative to the sustainability challenges they sought to address, the specific context in which activities took place, and the manner in which art-science integration was practiced. Across cases, however, art-science integration facilitated participants' learning, connection, and action for sustainability. Framed by the shared aims of transdisciplinary approaches, this manuscript discusses methodological hurdles and practical lessons learned in art-science integration across settings as well as the transformative capacity of alternative pedagogical and research practices in building a sustainable future.
\end{abstract}

Keywords Art-science integration $\cdot$ Community engagement $\cdot$ Sustainability science education $\cdot$ Transdisciplinary research $\cdot$ Transformative learning $\cdot$ Youth-led participatory action research

Handled by Eefje Cuppen, Universiteit Leiden Instituut Bestuurskunde, Netherlands.

Carlie D. Trott

carlie.trott@uc.edu

Trevor L. Even

trevor.even@colostate.edu

Susan M. Frame

jakmelekspresyon@gmail.com

1 Department of Psychology, University of Cincinnati, Cincinnati, $\mathrm{OH}$, USA

2 Department of Anthropology, Colorado State University, Fort Collins, CO, USA

3 Jakmel Ekspresyon Art Center, Jacmel, Haiti

\section{Introduction}

The urgency of radical societal transformation to sustainability underscores the necessity of alternative approaches to sustainability education through which communities can learn about, relate to, and collaboratively act for sustainability in local contexts. Given the daunting nature of sustainability challenges, there is especially a need for pedagogies that allow young people to engage with sustainability on their own terms and in ways that not only deepen their understanding, but also support their interest, active participation, and sustained engagement (Cutter-Mackenzie and Rousell 2019; Facer 2019; Holfelder 2019). In place of top-down models consisting of universal, competency-based 
solutions, ${ }^{1}$ it is critical that sustainability educators encourage learners to critically engage with present realities, envision alternatives, and take collaborative action for sustainability where they live. What pedagogical modes may facilitate these bottom-up processes, and through them, position young people as radical visionaries and change agents for a sustainable future today?

One possibility is to integrate the arts and sciences in action-oriented sustainability education (Skorton and Bear 2018). Sustainability challenges are simultaneously scientific and cultural in nature. Scientific discourses have dominated the sustainability literature to date, yet the arts, as drivers of culture (Kagan 2011), have a critical role to play in societal transformation to sustainability. Though the arts (like sustainability) resist a simple definition, in this manuscript, "the arts" refer to modes of expression-such as music, performance, painting, photography, and film - that use "skill or imagination in the creation of aesthetic objects, environments, or experiences that can be shared with others" (Kuiper 2016). ${ }^{2}$ Historically, the arts have been mobilized for social change- a way to resist and rewrite dominant narratives, spark critical dialogue around societal issues, and open the door to potential transformation. Towards cultivating cultures of sustainability, the arts have the potential to strengthen affective ties between people and places as well as other kinds of emotional bonds that spur action (Heras and Tàbara 2014; Kagan 2008; Singleton 2015). In educational contexts, the arts foster diverse ways of learning and understanding the world, which can be highly engaging and motivating to learners, especially young people (Heras et al. 2016; Sipos et al. 2008). Importantly, the critical role of the arts in facilitating societal transformation to sustainability, lies in their capacity "to create experience, make relationships, [and] expand mental activity" in ways that allow us

\footnotetext{
1 Following Wiek et al. (2012), use of the term "solutions" with reference to sustainability challenges does not imply simplicity, swiftness, or universality. As opposed to "a simple 'command and control' approach," addressing sustainability challenges requires "participation, coordination, iteration, and reflexivity" (p. 6; see also van Kerkhoff and Lebel 2006).

2 The National Foundation on the Arts and the Humanities Act, originally passed by the United States Congress (1965), defines "the arts" as follows: "The term 'the arts' includes, but is not limited to, music (instrumental and vocal), dance, drama, folk art, creative writing, architecture and allied fields, painting, sculpture, photography, graphic and craft arts, industrial design, costume and fashion design, motion pictures, television, radio, film, video, tape and sound recording, the arts related to the presentation, performance, execution, and exhibition of such major art forms, all those traditional arts practiced by the diverse peoples of this country. (sic) and the study and application of the arts to the human environment." This legislation established the National Endowment for the Arts and the National Endowment for the Humanities.
}

to reexamine our non-sustainable present realities and act towards alternative futures (Kagan 2011, p. 218).

Recent decades have witnessed a rise in forms of art-science integration that infuse the STEM disciplines (science, technology, engineering, and math) with the arts (e.g., via STEAM programming), particularly in K-12 settings (Land 2013; Taylor and Taylor 2017). More often than not, however, such practices have tended to instrumentalize the arts for the purpose of science learning (Psycharis 2018), rather than to activate the transformative potential of the arts for social change. Put differently, art-science integration has typically been an instructional means to transmit information about 'what is,' rather than an invitation to imagine 'what if?' Moreover, there is limited empirical evidence around how to approach, design, and implement STEAM education (Quigley et al. 2017, 2019), and few published studies have explored practical challenges related to these forms of integrated engagement (Herro et al. 2019). What are the possibilities and challenges of art-science integration in the context of sustainability education? And how, might sustainability scholars, educators, and advocates integrate the arts and sciences in ways that enable children and youth ${ }^{3}$ to envision and enact sustainable alternatives at the local level?

This manuscript presents a pair of case studies experimenting with art-science integration for sustainability action in widely different settings: a climate action project in the Western US and a water advocacy project in Southern Haiti. Despite great variation in context and application, each case study used community-engaged participatory research methods in collaboration with children and youth, while mobilizing art-science integration for collaborative sustainability action in local settings. Before offering case study descriptions, this manuscript first reviews literature relevant to art-science integration for enabling young people to envision and enact sustainable alternatives. Building on this literature review, we present a methodological framework for transdisciplinary learning and collaborative sustainability action that shaped — and was shaped by—participatory processes taking place within each community context. Next, each element of the framework is used to describe the key components and action-based outcomes of each case study. Finally, alternative pedagogical and research practices, such as those described in this manuscript, are discussed in terms of their transformative potential towards building a sustainable future.

\footnotetext{
Given that age-based categories are not fixed across time and space, there is no universally agreed-upon age range associated with "youth" (Corner et al. 2015; Fisher 2016). Here, "youth" is defined as under eighteen years of age.
} 


\section{Literature review}

The following sections offer a detailed literature review that knits together disparate literatures dealing with sustainability education, ${ }^{4}$ art-science integration, ${ }^{5}$ and youth-led sustainability action. First, we trace linkages between the history of disciplinary fragmentation in research and education to present-day efforts to reintegrate the arts and sciences in informal and non-formal educational settings. Later, we discuss the transformative potential of alternative pedagogies that facilitate youth-led sustainability action.

\section{Sustainability as science}

A widely cited definition of sustainability comes from the World Commission on Environment and Development's (1987) Brundtland Report—also known as Our Common Future - which characterizes sustainable development as that which "meets the needs of the present generation without compromising the ability of future generations to meet their own needs" (p. 8). The inherent complexity of sustainability, as a concept and a practice, is apparent when considering its implied emphasis on multi-dimensional "linkages and interdependencies of the social, political, environmental, and economic dimensions of human capabilities" (Davis 2015, p. 10; Pipere 2016). Recognizing this, sustainability challenges have often been characterized as wicked problems, or those with complex, ever-changing conditions and whose solutions can be contradictory, contested, or cause problems of their own (Rittel and Weber 1973). From this perspective, sustainability topics intersect with, and give life to all of the traditional school subjects (e.g., social studies, math) and have been integrated across the curriculum (Cook 2019; Hicks 2014). Despite this, when sustainability is introduced in the US classroom, it is most often from the exclusive perspective of science ${ }^{6}$ (Bourn et al. 2017).

Formal education in Western societies rests on a foundation of rationalism, which holds that knowledge arises from

\footnotetext{
4 There are many terms referring to 'environment-related education' in the sustainability domain (Hart and Nolan 1999; Håkansson et al. 2019). Following Sterling (2004) and Pipere (2016), in this manuscript, the term "sustainability education" is used to refer to various approaches including education for sustainable development (ESD), education for sustainability (EFS), environmental sustainability education (ESE), and education for a sustainable future (ESF).

5 In this manuscript, the term "art-science integration" is used to refer to any kind of educational initiative integrating the science, technology, engineering, and mathematics (i.e., STEM) disciplines with the arts (e.g., STREAM, STEMM, ST ${ }^{2}$ EAM, ArtSTEM; Land 2013; Taylor and Taylor 2017).

6 This is not the case everywhere. See Birdsall (2013) for an argument for the reintegration of science and sustainability education in New Zealand.
}

specific modes of inquiry such as observation, evidencegathering, and scientific reasoning. This dominant paradigm is responsible for fragmenting knowledge into discrete disciplines-and consequently, school subjects-because, in order to know the world through these means, it was necessary to break it down into smaller and smaller elemental parts. Through this process of dis-integration, certain disciplines (e.g., the sciences) came to be held in greater esteem than other disciplines (e.g., the arts) to the extent that their epistemic values aligned or dis-aligned with the rationalist perspective. In particular, the sciences-which place a premium on "objectivity, certainty, universality and predictability" - came to be valued over the arts, which tend to embrace a wider range of knowledge sources, including emotion, intuition, memory, and spirituality (Sipos et al. 2008; Cook 2019). In a 1998 essay entitled Back from the Chaos, E. O. Wilson spoke of the wide chasm between the arts and sciences, noting that "the ongoing fragmentation of knowledge and the resulting chaos in philosophy are not reflections of the real world but artifacts of scholarship."

Despite the widespread adoption of constructivist pedagogies in the classroom over recent decades, the legacy of Western education's rationalist roots survives not only in the existence of school subjects, but in the language of scientific objectivity and subject matter that can feel "devoid of story, attachment and meaning" (Sipos et al. 2008; Phelan 2004). What this means for learning is that students may struggle to find ways to connect to or identify with abstract science concepts despite their real-world significance (Birdsall 2013; Hodson 2003; Lester et al. 2006).

In the research laboratory as in the classroom, efforts around disciplinary integration, including cross-, multi-, inter-, and transdisciplinary approaches, have in recent decades sought to reverse the deep fragmentation that is rooted in rationalism (Weinberg and Sample-McMeeking 2017). Sustainability has long been a key site for this reintegration process (Cook 2019; Roy et al. 2019; Yarime et al. 2012). The 'wickedness' of sustainability challenges, combined with their high stakes for humanity, have ushered in an era of increasingly integrated research agendas and pedagogies. However, in sustainability research and education, this growing cross-pollination and collaboration has taken place primarily across the boundaries of various science fields and much less with the arts (Kagan 2011; WCED 1987).

\section{Art-science integration for social change}

In this increasingly welcoming atmosphere towards a wider array of epistemic traditions, art-science integration has been proposed as a way to breathe new life into science teaching and learning. Specifically, so-called "STEAMbased" programming has been advanced as a remedy both to problems of disciplinary fragmentation and towards reviving 
students' affective and intuitive connections with STEM disciplines by illuminating their personal and real-world significance through creative processes (Land 2013; Taylor and Taylor 2017). STEAM-based curricula have been characterized as "an opportunity to inject creativity into courses that have traditionally been more scientific in nature" (Marmon 2019 , p. 101). For example, in a large study of STEAM curricula, fourth grade classrooms merged the arts and sciences to design a prosthetic arm, explore how scientists recreate extinct animals, and investigate how engineers design roller coasters (Bush and Cook 2019). In a 2018 report examining the benefits of integrated art-science programming in higher education contexts, the National Academies of Science, Engineering, and Mathematics (NASEM) note that:

The arts teach creative means of expression, understanding of different perspectives, an awareness of knowledge and emotions throughout the human experience, and the shaping and sharing of perceptions through artistic creation and practices in the expressive world. (Skorton and Bear 2018, p. 60)

Powerful actors, including governments, institutions of higher education, and industry have increasingly embraced art-science integration, as noted in the inaugural issue of the STEAM Journal: "Government agencies are beginning to acknowledge that art and science-once inextricably linked, both dedicated to finding truth and beauty-are better together than apart" (Maeda 2013, p. 1). Research and programming around such integration has grown in recent years, particularly in informal learning contexts, as has discussion and debate around its specific aims, organization, and implementation-as indicated by the existence of numerous related but distinct titles (e.g., STREAM, STEMM, ST ${ }^{2}$ EAM, ArtSTEM, Land 2013; Taylor and Taylor 2017).

Considered holistically, integrated art-science engagement with youth seems like a worthwhile endeavorespecially around deepening understanding and critical engagement with sustainability challenges. For one, it offers a pathway towards bridging the kinds of dividesconstructed (e.g., emotion-reason) and institutionalized (i.e., art-science) - that would appear to hinder sustainable transformation. Moreover, to borrow the language of interdisciplinarity, art-science integration holds the promise of bringing together "different disciplinary ideas and methods ... [which] can result in novel, unexpected answers to familiar, timeworn questions" (Toomey et al. 2015 , p. 1). However, a strong theme across its various configurations and a seeming limitation is that the arts are typically integrated with STEM disciplines for the purpose of deeper STEM engagement (Liao 2019). In other words, when art-science integration occurs, the arts are mobilized almost exclusively in the service of science, either as a way of concretizing abstract subject matter or cultivating students' active participation in ways that stimulate their creative thinking, feeling, or personal connection (Psycharis 2018). Ultimately, the arts are instrumentalized towards strengthening students' sustained STEM interest and engagement, thus reproducing-rather than dissolving-existing disciplinary hierarchies in the name of interdisciplinarity. More generally, the stated purpose of integrating the arts and sciences is often to deepen students' content knowledge (i.e., learning "what is"), rather than to promote students' critical engagement with reality and spur social transformation (i.e., asking "what if?"). A distinction articulated by radical educational theorist Paolo Freire (1972) is relevant in this regard:

Education either functions as an instrument which is used to facilitate integration of the younger generation into the logic of the present system and bring about conformity or it becomes the practice of freedom, the means by which men and women deal critically and creatively with reality and discover how to participate in the transformation of their world.

Given the gravity of sustainability challenges and the urgency of cultural transformation, there is a need for integrated art-science pedagogies that build upon the historical legacy of the arts in prompting social change. At present, however, there is reason to suspect that infusing the arts into STEM teaching and learning through novel pedagogies is a sort of rebranding effort for science and technology disciplines. In many STEAM-based curricula, the arts are an "add-on experience", keeping more or less intact traditional approaches to STEM teaching and learning (Quigley et al. 2019, p. 143). Moreover, rather than delivering the promised paradigm shift, much art-science integration appears poised to uphold non-sustainable present-day conditions. On a societal level, building the STEM workforce through innovative recruitment and retention strategies (e.g., art-science integration) is, at its core, a way to shore up global economic competitiveness; a brimming STEM 'pipeline' ensures continued leadership in innovation over the decades to come (Maeda 2013; National Science Foundation 2015). As the founder of the STEAM Journal put it:

With global competition rising, America is at a critical juncture in defining its economic future. I believe that art and design are poised to transform our economy in the 21 st century like science and technology did in the last century, and the STEAM movement is an opportunity for America to sustain its role as innovator of the world (Maeda 2013, p. 1).

While this statement promises transformation, the goal of maintaining US global dominance, via STEAM, reveals a preference for the neoliberal status quo. Put differently, 
just as global sustainability crises demand that we reexamine (and resist) dominant narratives around individualism, consumerism, and competition, art-science integration is framed here as a way to give the US the perpetual upper hand.

The realities of global sustainability crises challenge us to envision alternative structures and institutions, such as Jackson's (2017) notion of 'the economy of tomorrow,' which redefines prosperity in terms not of material concerns, but of human and ecological well-being. From a sustainability perspective, then, current applications of STEAM (and similar integrative approaches) do not appear particularly transformative. Outside of "learning through the arts" to "enrich learning in disciplines beyond the arts" (Ghanbari 2015, p. 3; Hetland 2013), how might we rethink art-science integration in the context of global transformation to sustainability? For example, what would it look like to see art-science integration as existing on a continuum, which, on one end mobilizes science in the service of arts-based activism? Moreover, what would it mean to integrate art and science for the purpose of envisioning and enacting alternative futures?

\section{Transformative learning for youth-led sustainability action}

Despite prevailing trends in STEAM education, a number of educational programs in the sustainability realm have sought to engage young people in various forms of social change action, most often in non-formal educational settings (PercySmith and Burns 2013). Taking seriously the notion that information dissemination (i.e., science learning) is insufficient to the task of societal transformation, these educational initiatives have sought to facilitate transformative learning by engaging the 'whole person' and emphasizing knowledge, values, and action (Jensen and Schnak 2006; Sterling 2001). These pedagogical practices have been advocated under a variety of names, including (but not limited to) education for sustainable development (ESD; UNESCO 2019), environmental education for empowerment (Palmer 1998), science education for action (Hodson 2003, 2011; Jenkins 1994), and education for sustainability (Singleton 2015). Such approaches share an ethos that mobilizing people in sustainability requires not only the act of collectively constructing visions of sustainable transformation but linking them to opportunities for action (Meadows and Randers 1992). Indeed, in order to "achieve sustainable human well-being and the flourishing of a non-human world", we must engage with young people as "citizens who care about sustainability and who are supported and able to act on their concerns" (Hayward 2012, p. 5, emphasis added; Hodson 2011). Given dominant cultural narratives that regard young people not as human beings but as "human becomings"- thus limiting their sociopolitical inclusion-it is also important that children play a role in choosing, planning, and taking action for sustainability in ways that support their sense of agency (Qvortrup 2009).

A primary goal of action-based educational initiatives has been to empower young people as agents of change within their families and communities. In the context of sustainability, youth who are "environmentally empowered" are confident in their own abilities to "make a difference in the world, both by daily, personal choices related to lifestyle and by influencing [others]" (Schreiner et al. 2005, p. 8). Research emphasizing the potential role of young people as agents or catalysts of change in their families and communities often points to the efficacy of intergenerational influence as a means for youths' active, influential, and critical position in the transformation of their environments (Ballantyne et al. 1998; Percy-Smith and Burns 2013). Given a stubborn focus on individual rather than collective action in sustainability education contexts, however, there is a need for "engag[ing] differently" in ways that map onto the largescale transition that is now required (Jorgenson et al. 2019, p. 168). Studies of youth social action consistently find that when young people are given opportunities to explore their voice and communicate their concerns in the public sphere, they can develop competencies often linked to empowering, participatory outcomes (Foster-Fishman et al. 2005; Malone 2013; Roth and Lee 2004). For example, in a study by Johnson et al. (2013), after participating in a youth development program "designed to increase knowledge and capacity for leadership and action in response to climate change" (p. 29), Ugandan youth reported increased self-efficacy, social and political awareness, commitment to civic action, and leadership. Moreover, collaborative action can be a way for young people to manage their feelings of frustration and powerlessness in the face of sustainability challenges, while creating tangible change within their communities (Trott 2019a, b).

Though limited, studies of children's collaborative sustainability action using arts-based methodologies suggest similarly beneficial outcomes. In particular, children's sense of political agency has been supported through the act of advocating for sustainable alternatives through the visual and performing arts (Haynes and Tanner 2015; Osnes 2017; Rooney-Varga et al. 2014; Stratford and Low 2015). In a 2-year study, Stratford and Low (2015) collaborated with children in an arts-based initiative called A Map of a Dream of the Future, in which children and adults co-created climate change educational materials and an art installation. As the authors explained, "children are more readily attuned to their political impulses when supported in creative, participatory engagements" (p. 167). In another long-term study, called Climate Change and Me, 9 to 14 year-olds, as co-researchers and co-artists, developed an online social media platform and network, organized community exhibitions, designed an interdisciplinary curriculum, 
and held a community event that brought together artists, scientists, and schools to address challenges related to climate change (Cutter-Mackenzie-Knowles and Rousell 2018). After describing children's creative outputs through this participatory project, the authors theorize the use of digital video as a "transitional medium" that allowed young people to experiment with new forms of "creative resistance" (p. 2) while developing their own ways of responding to climate change.

Transcending its common application in STEAM-based pedagogies to date, the arts offer more than a mechanism through which to promote content learning. They can be activated to spark and sustain much-needed processes of societal change in response to sustainability challenges. As mentioned, the arts have been a key medium through which marginalized groups may raise awareness of critical issues, challenge unjust norms, and provoke the social imaginary to think and become otherwise. In the context of sustainability, art-science integration can be a portal through which to contemplate the past, confront the present, and create immediate and eventual futures. Integrating the arts into sustainability education opens the possibility of deepening children's place-based awareness of sustainability challenges, while forming a foundation for shared meaning-making, emotional connection, and collaborative action planning in local settings. Moreover, by practicing epistemic fluidity, art-science integration represents a promising avenue for facilitating transformative sustainability learning for purposes of critical reflection and invoking "new ways of thinking and being" in the world (Sipos et al. 2008, p. 71). Despite these transformative aspects, questions remain about how to design and implement integrated art-science programming in ways that position young people as change agents in their communities.

\section{The present research}

This manuscript explores the possibilities and challenges of art-science integration in sustainability education contexts. Through the lens of two case studies, we-an interdisciplinary team with backgrounds in social and environmental sciences as well as the arts-engage with the question of how we might integrate the arts and sciences in ways that enable children and youth to envision and enact sustainable alternatives within their communities. The US case study was the first author's dissertation research; the Haiti case study is an ongoing collaboration between all co-authors of this manuscript. The first author has backgrounds in social and community psychology as well as arts management, the second author has backgrounds in anthropology and ecology, and the third author has a background in the arts and is the Founder and Director of the arts center in Southern Haiti.
Before turning to case study descriptions, we feel it is necessary to provide a broad overview of our approach to art-science integration across case studies. First, there is no widely agreed-upon definition of integration, as noted in a 2018 NASEM report that explored the practice of "intentionally integrat[ing] knowledge in the arts, humanities, physical and life sciences, social sciences, engineering, technology, mathematics, and the biomedical disciplines" in higher education contexts (Skorton and Bear 2018, p. x). In general, however, to integrate means to unite, or "to form, coordinate, or blend into a functioning or unified whole" (Merriam-Webster 2019). In educational settings, "integration" is an umbrella term encompassing a range of integrative approaches (e.g., inter-, cross-, multi-, and transdisciplinarity), and it typically involves "merg[ing] contents and/ or pedagogies traditionally occurring in one discipline with those in other disciplines in an effort to facilitate student learning" (Skorton and Bear 2018, p. 64). In the present research, integrated art-science activities merged a number of relevant science disciplines with the arts towards addressing sustainability challenges.

The specific artform in both cases was digital photography guided by photovoice methodology. As a research method, photovoice is a form of participatory action research (PAR) that aims to give voice to marginalized groups in the process of gaining awareness and acting on critical societal issues (e.g., Wang et al. 2004). As an arts-based methodology, photovoice is grounded in the tradition of documentary photography. In this tradition, photographic images aim to capture real-life settings and situations as a means of "bearing witness to world events", and is often-through its dissemination in galleries and museums-a "tool for social change [used] to shed light on injustice, inequality and the sidelined aspects of society" (Tate 2019). Photovoice has traditionally been used as an action-oriented research method but has been adapted for use in educational settings (Cook 2015). Modified photovoice practices are increasingly observed in environmental education settings (Derr and Simons 2019). In the present research, photovoice is both a way to strengthen children's understanding of, and connections to today's sustainability challenges (i.e., "what is") and to invoke their democratic imaginations (i.e., "what if?") about a more sustainable tomorrow through presentday projects. Contrasting sharply with the trend of instrumentalizing the arts for knowledge acquisition, photovoice methodology instrumentalizes the camera as a machine for generating social change through critical engagement with present-day realities. Put differently, youths' photography in this sustainability education context invoked "alternative ways of seeing, recording and understanding the events and situations that shape the world in which we live", opening up possibilities for envisioning alternative futures (Tate 2019). 
Table 1 Case study overview: participant, research team, and program characteristics

\begin{tabular}{|c|c|c|}
\hline & Science, Camera, Action! (US) & Photo Environment (Haiti) \\
\hline Participants & Children (ages 10-12) & $\begin{array}{l}\text { Cycle 1: youths (ages 8-14). Cycle 2: youth and young } \\
\text { adult participants (up to } 21 \text { years) }\end{array}$ \\
\hline Context & Western US; National non-profit (Boys and Girls Clubs) & Southern Haiti; Community organization (Arts Center) \\
\hline Program design & After-school program (three sites) & Arts center course (two cycles) \\
\hline Duration & 15 weeks (1-hour-long session per week) & $\begin{array}{l}\text { Cycle 1: } 15 \text { weeks ( } 1 \text { session/week); Cycle 2: } 8 \text { weeks (2-3 } \\
\text { sessions/week) }\end{array}$ \\
\hline $\begin{array}{l}\text { Program team discipli- } \\
\text { nary backgrounds }\end{array}$ & $\begin{array}{l}\text { Psychology, Arts Management, Engineering, Communi- } \\
\text { cations, and Early Childhood Education }{ }^{\mathrm{a}}\end{array}$ & $\begin{array}{l}\text { Psychology, Arts Management, Ecology, Anthropology, } \\
\text { Fine Arts, and Film }\end{array}$ \\
\hline Sustainability challenge & Climate change & Water security \\
\hline Science components & $\begin{array}{l}\text { Hands-on activities connecting the topics of climate } \\
\text { change, ecosystems, and community-based sustainabil- } \\
\text { ity action (e.g., Greenhouse Gas Tag; Energy Bingo) }\end{array}$ & $\begin{array}{l}\text { Water literacy education, including water-testing kits and } \\
\text { day-tips to local water sources (e.g., rivers, streams), } \\
\text { with a focus on hydrology, water management, and clean } \\
\text { water access }\end{array}$ \\
\hline Arts components & $\begin{array}{l}\text { Digital photography and hand drawings inspired by chil- } \\
\text { dren's personal and place-based connections to program } \\
\text { activities; provided the inspiration for youth-led com- } \\
\text { munity action projects }\end{array}$ & $\begin{array}{l}\text { Digital photography and documentary film-making to cap- } \\
\text { ture the beauty and necessity of (and challenges related } \\
\text { to) water in Southern Haiti; provided the raw material for } \\
\text { community events }\end{array}$ \\
\hline Social change outputs & $\begin{array}{l}\text { Photo gallery exhibition; website; city council presenta- } \\
\text { tion; tree-planting campaign; community garden }\end{array}$ & $\begin{array}{l}\text { Photo gallery exhibition; community-led water-testing } \\
\text { analysis; documentary films }\end{array}$ \\
\hline
\end{tabular}

${ }^{a}$ Educational backgrounds refer to the first author and five undergraduate research assistants who helped facilitate the program in 2016

${ }^{b}$ For a more detailed description of program activities, see Trott (2019a)

\section{Case studies in art-science integration for collaborative sustainability action}

The following sections introduce a pair of case studies in art-science integration for collaborative sustainability action: (1) a multi-site research study and after-school program for climate education and action in collaboration with children in the Western US; and (2) a multi-cycle research study and youth-focused course for environmental photography and water advocacy in Southern Haiti. Both projects took place in non-formal learning contexts (i.e., community organizations), and combined transdisciplinary learning with digital photography as an integrated art-science platform for collaborative sustainability action in local settings (see Table 1). Despite these shared characteristics, the case
Fig. 1 Methodological framework for transdisciplinary learning and collaborative sustainability action through the integration of art and science

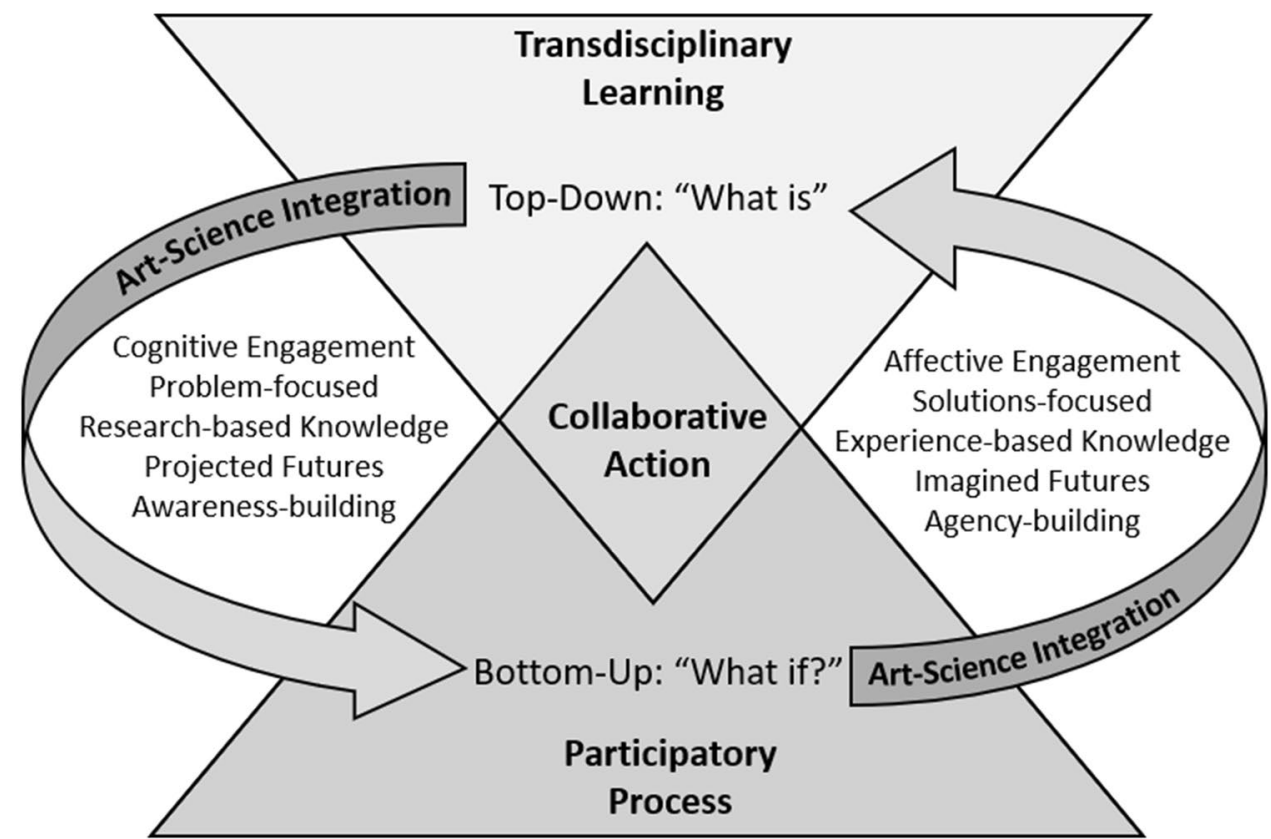




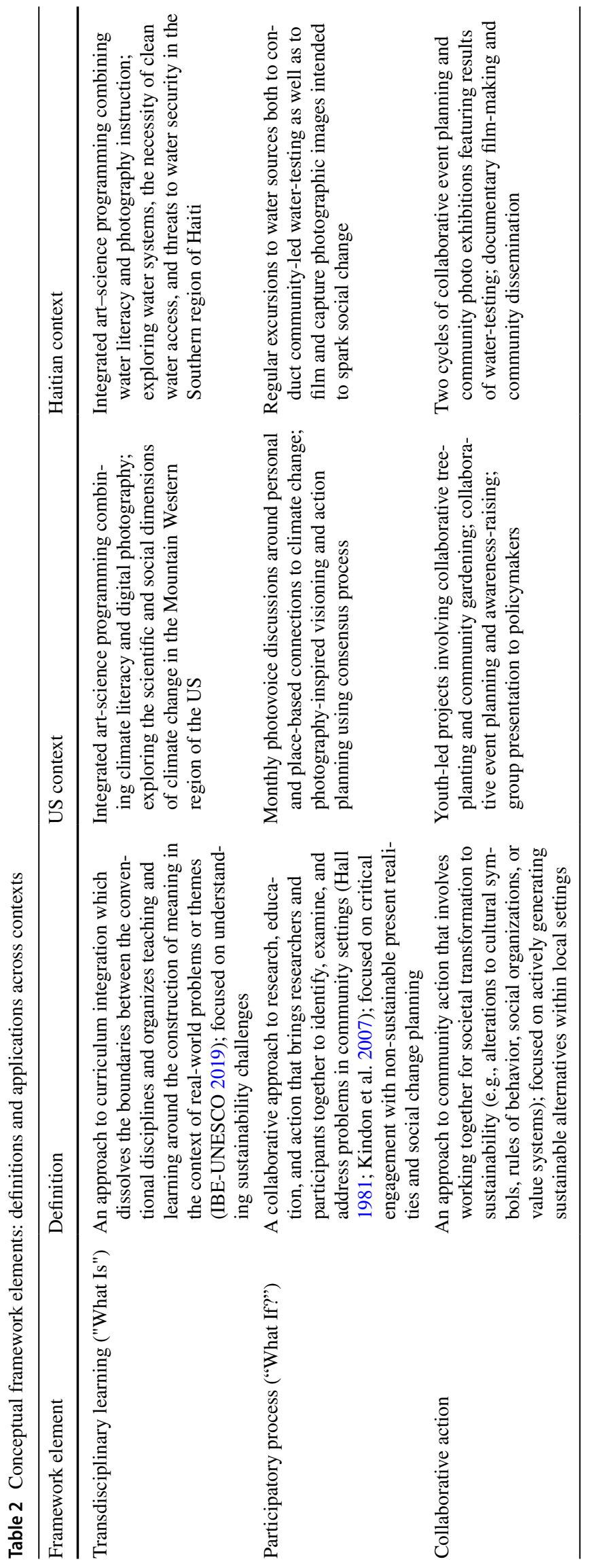


studies diverge in important ways relative to the sustainability challenges they sought to address, the specific context in which learning and action took place, and the manner in which art-science integration was practiced. The design of each case study was guided by iterations of the methodological framework introduced below, and the implementation of each case study, in turn, contributed to framework development. As such, the divergent aspects of the case studies (i.e., geographic region, sustainability challenge, integrated art-science practices) contributed to a methodological framework that is more versatile than if developed from a single case. Moreover, these divergent aspects allowed for a deeper exploration of the possibilities and challenges of art-science integration in different contexts. In the following sections, we introduce the methodological framework, followed by detailed case study descriptions. Both studies were approved by the institutional review boards at the universities where the research took place.

Figure 1 presents a methodological framework for transdisciplinary learning and collaborative sustainability action through the integration of art and science. Specifically, the framework combines: (1) transdisciplinary learning, centered on real-world problems, with (2) participatory process, facilitating learners' personal connections to sustainability challenges, and culminates in (3) collaborative action for sustainability, allowing learners to both envision and enact alternative futures. In the US and Haiti, program activities were shaped by the 'Head, Hands, and Heart' model for transformative sustainability learning (Sipos et al. 2008) and inspired by photovoice methodology for purposes of sustainability learning, placed-based inquiry and connection, and social change (Cook 2015). For definitions of each framework element as well as brief overviews of their specific applications across case study contexts, see Table 2 .

\section{Child-led climate action in the Western US}

The after-school program Science, Camera, Action! was designed to engage 10- to 12-year-olds in place-based climate change education and collaborative, community-based climate action over a period of 15 weeks in the spring of 2016. Altogether, 55 children participated in the program across three Boys and Girls Clubs (BGC) located in the Western US. Together, the three participating Clubs represented a regional division of the $\mathrm{BGC}$ and were located within a 20-mile radius of the research university. The BGC is one of the largest youth-serving non-profit organizations in the US, currently with over 4600 Club locations (BGC 2019). Founded in 1860 , the BGC serves over four million youth every year, most of whom live in poverty (BGC 2019). The university-community partnership on which this research is based was established through a pre-existing relationship between local BGC staff and a Center at the nearby research university, which focused on STEM education and outreach. In particular, the regional BGC was looking to incorporate STEAM programming into its afterschool services. Following a series of meetings in late 2015, the BGC welcomed Science, Camera, Action! into all three of its regional Clubs. These BGCs varied in size and the nature of their programming-from small and informal to large and highly coordinated. The mission of the BGC is "to enable all young people, especially those who need us most, to reach their full potential as productive, caring, responsible citizens" (BGC 2019). The program was mission-aligned through its engagement of local children in transdisciplinary learning and youth-led collaborative action for sustainability.

The Western state where this research took place is among the majority of US states not to require anthropogenic climate change to be taught in the classroom (National Science Teachers Association [NSTA] 2019). Among the only guidelines related to climate change in the state's plan, eighth grade teachers of Earth systems science are encouraged to cover "inquiry questions" about climate change such as, "What evidence supports and/or contradicts human influence on climate change?" and, "How has Earth's climate changed over time?" What this means for 10 to 12 -year-olds (i.e., in fourth to seventh grade) is that, despite likely exposure to climate change information elsewhere in their lives (e.g., news, movies, zoos; Kelsey and Armstrong 2012), they may not learn about these topics in the classroom until their teenage years, and even then, in ways that may or may not align with established research. As such, there was a need, locally, not only to provide young people with access to evidence-based information about climate change, but also to create empowering learning environments where children are invited to engage with complex sustainability topics, make sense of them on their own terms, and act towards sustainability in ways that align with their visions for alternative futures.

The program's name, Science, Camera, Action!, is a play on the popular film director phrase "Lights, camera, action!" and was chosen because program activities closely aligned with each of these domains. The program's initial activities-under the category "Science" - consisted of various hands-on activities and games focused on important social and scientific dimensions of climate change (see Trott 2019a). For example, activities that sometimes mirrored common children's games focused on how the greenhouse effect works (i.e., Greenhouse Gas Tag), what kinds of local and global ecosystem impacts to expect under a changing climate (i.e., Oh Deer! and Glaciers: Then and Now), what daily behaviors relate to climate change (i.e., Energy Bingo), and how kids have worked together in other places around the globe to collaboratively make a difference (i.e., Young Voices for the Planet videos). The final two activities were paired with discussions about how we can take meaningful 
steps towards enacting sustainability, both individually and as a group. These activities-running the gamut from explaining "what is" to asking "what if?"- were integrated with the program's "Camera" component.

Guided by photovoice methodology, children were asked to use program-provided digital cameras to capture images expressing their thoughts and feelings about each program topic. Approximately half of US program participants received introductory training in photographic techniques (e.g., composition) through a field trip and photo excursion at a local ranch. Photographs were intended to facilitate children's affective and intuitive connection-making between program activities, their everyday lives, and their real-world hopes and concerns, forming the basis for group discussion and action project planning. When children forgot to take photographs or bring their camera to the program, they were asked to draw their ideas on paper. The content of children's photographs and drawings varied widely and included, for example, family members (e.g., a baby representing the "next generation"), animals (e.g., cows representing methane emissions; pets), and landscapes (e.g., a beautiful sunset; pollution). In these ways, children's photographs represented the people and places about which children cared deeply and wanted to protect, as well as perceived environmental threats. Three times throughout the program, children participated in photovoice group discussions in which they narrated their printed photographs or drawings according to the SHOWeD method, ${ }^{7}$ which asks children a series of questions ranging from "What do you See here?" (i.e., "what is") to "What can we Do about it?" (i.e., "what if?"; Cook and Quigley 2013; Wang et al. 2004).

Finally, the children were supported in designing and implementing family- and community-focused "Action" projects, inspired by program activities and their own digital photography, to address climate change in ways that aligned with their interests and visions around sustainability. Specifically, children at each research site viewed a compilation of their own favorite photographs generated over a period of 10 weeks, then brainstormed action ideas by writing down any collaborative project idea that came to mind. Program facilitators captured all ideas and condensed them into thematic groupings

\footnotetext{
7 According to the SHOWeD method, photovoice discussions explored the specific content of children's photographs as well as what can be done about problems depicted. In these ways, photovoice discussions prompted children's "what is" and "what if?" thinking. The following is a list of SHOWeD question prompts, in order: "What do you see here? What is really happening? In other words, what may not be clear about your photo but is important for you to explain? How does this relate to Our lives? Had you thought about this connection before? Why does this problem or strength exist? What can we Do about it? What are the challenges? What are the opportunities?" (Cook and Quigley 2013; Wang et al. 2004).
}

presented the following week to children at each of the three research sites. Children then discussed their favorite action project ideas and, at two research sites, chose to combine a pair of popular ideas for action. Children's action projects consisted of tree-planting and community gardening as well as awareness-raising with local adults (e.g., family and community members via a photo gallery exhibition and website) and policymakers (e.g., via a city council presentation). Most action projects were completed within the 15 -week program period, but the children who established a community garden formed a summer garden club and continued working together for an additional few months. As described elsewhere, Science, Camera, Action! was among the most popular non-sport programs the local BGC Activities Director had seen across the BGC region, and children's enthusiastic engagement was apparent to program facilitators from week to week and across research sites (see Trott 2019a). For more detailed descriptions of program activities, see Trott 2017; for more detailed descriptions of children's action projects, see Trott 2019a.

In Science, Camera, Action!, transdisciplinary learning took place through centering the real-world problem of climate change, and allowing children to explore this complex, multi-faceted problem among a disciplinarily diverse group of program facilitators (see Table 1) and through hands-on activities based in diverse disciplinary traditions, including various science (e.g., ecology, physics, atmospheric science) and social science (e.g., psychology) disciplines, as well as through art (i.e., photography) and art-inspired action (i.e., community projects). Importantly, children's action projects were shaped by transdisciplinary learning combined with participatory process through art-science integration: children's photography offered a way for them to make sense of climate change in relation to their own lives and the things they care about, to share in this sense-making process with each other, and to act on the problem according to their own present-day concerns and aspirations for the future. At two of three research sites, children's photographs became a primary mode of communicating about climate change with adults-first, in a public presentation during which children advocated for swift action on climate change with local policymakers, and second, through a photography exhibition during which children explained their photographs to local adults as a way to encourage climate change awareness and action. In these ways, children's photographs became "artistic boundary objects" (Rathwell and Armitage 2016) — a way of translating meaning "across social worlds" to generate social change (Star and Griesemer 1989, p. 388). 


\section{Youth-led clean water advocacy in Southern Haiti}

One year after Science, Camera, Action! ended, in spring 2017, a new university-community partnership formed between the lead author and the Director (and founder) of a community arts organization in Southern Haiti dedicated to creating "a space for all people to learn, explore, develop, and express a voice through creative mediums." The Director was looking to incorporate STEAM into their otherwise arts-focused programming, due in part to the fact that many schools in the area covered only theoretical science content, limiting students' practical and lab-based experience. The Photo Environment course was born out of a conversation about the integrated art-science framework used in Science, Camera, Action!, specifically its combination of STEM and photography for local action. In particular, the combination of photography with environmental awareness and action aligned seamlessly with the interests and ongoing efforts of an arts center educator who had been filming a documentary about access to clean water in the region.

It is difficult to overstate the seriousness of the numerous challenges faced by Haitian citizens when tasked with acquiring clean, safe, and reliable water. Roughly two-thirds of people living in this area of Southern Haiti live in absolute poverty (i.e., less than one dollar a day), and with its main livelihoods comprising non-irrigated maize cultivation, at-home charcoal manufacture, and, in the highlands, banana production, it faces significant exposure to climate-driven hazards such as flooding, erosion, landslides, and severe ecological and social drought (ECVMAS 2012). Although not impacted as severely by the 2010 earthquake as its neighbors to the north, the area nevertheless continues to face challenges in providing basic services, as well as multiple long-standing challenges to local water security, including contamination of river water from agricultural runoff, sewage, and refuse, fresh-water salinization resulting from seawater infiltration, and limited water supply during the area's December to March dry season. As of 2012, just over half the population had access to an "improved" source of water (e.g., underground pumps or gravity-fed wells), and less than a quarter had access to improved sanitation (ECVMAS 2012).

Despite these challenges, residents of Southern Haiti have shown an avid engagement in efforts to better manage their community's common pool resources, with numerous local programs currently underway to address a variety of social and ecological issues, ranging from anti-discrimination and anti-violence campaigns to deforestation prevention and community garbage clean-up and management. In this, they draw upon a long-standing local history of activism and artistic engagement with social issues, as well as a deep desire to develop local capacities to such a level that continued reliance upon international NGO-driven service provisioning is no longer necessary. The community arts center and research partner, for example, is an organization whose mission is rooted in social justice, radical inclusivity, and the creative arts.

The arts center course, Photo Environment, was designed to engage local Haitian youth in place-based education about photography and local water systems as a platform for local action. The multi-cycle course has taken place twice-once in the fall of 2017 and again in the summer of 2018. The first cycle was open only to youth participants (ages 8-14), butbased on the enthusiastic requests of community members and arts center educators - the course expanded to include youth and adult participants in the second cycle. To date, 21 students (i.e., 19 youth; two adults) have participated in the course. Participants have enjoyed their participation in the course and a third cycle is planned for spring 2020.

Educational program content integrated science topics (i.e., water systems, quality, and management) with the arts (i.e., digital photography), and emphasized the transformative potential of creative expression to generate positive social change. Educational activities focused on: (1) using digital cameras to capture and communicate ideas and issues; (2) generate shared sense-making around the sources, critical importance, and local problems related to water (i.e., pollution; policy) in Southern Haiti; and (3) create a platform for community action towards a more sustainable future. As part of the course, students took day-trips to regional water sources (e.g., rivers; streams; open community cisterns), photographed water resources and problems, and collected water samples for testing. Throughout the program, students discussed the content of their photographs in terms of the beauty of the region, its challenges related to climate change and pollution, and what could be different. For many students, the water-testing component was their first experience with science education that allowed them to gather evidence, develop hypotheses, and analyze results with the goal of answering pertinent local natural resource questions.

Building on these processes of data gathering and shared sense-making around issues of water security, over both cycles of the course, students organized and held photography exhibition events featuring their own local water-focused photography and the results of water testing. After processing the water-testing kits and analyzing results, water quality analyses were presented to local community members and policymakers at the events. The students also introduced and screened brief documentarystyle films describing the course and featuring the voices and actions of youth and educators. Together, the photography, film, and water quality reports were intended to raise awareness and spur further sustainability action. Events over both cycles were attended by local Haitians, UN officials, missionaries, NGO workers, students, and 


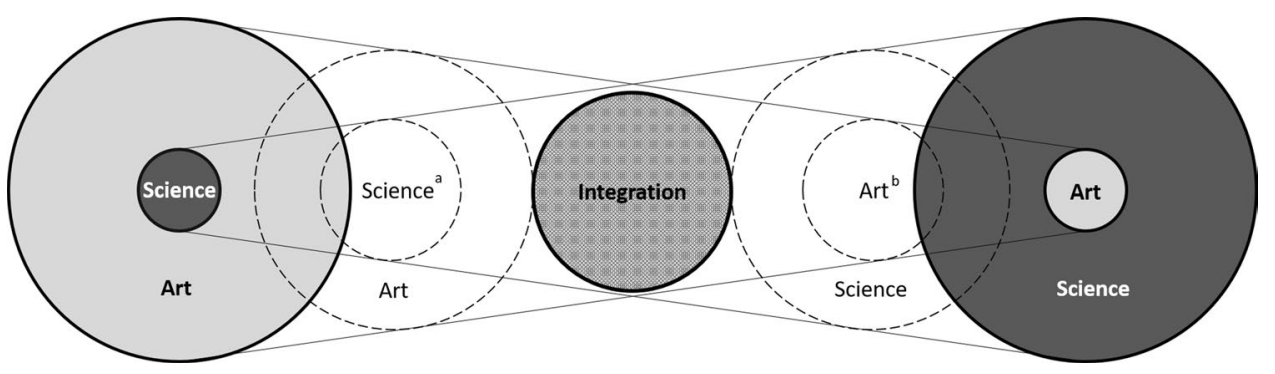

Fig. 2 Spectrum of art-science integration. The center of the figure represents the kinds of art-science integration in which neither the arts nor sciences are considered primary, central, or elevated compared to the other. The far left and far right represent the kinds of artscience integration in which one component is central and the other

their families. Following the first exhibition, school directors, NGOs, and orphanages began visiting the community arts center to learn more about its programming and to identify opportunities for partnership. During cycle 2, students and educators began alerting neighborhood residents in areas where filters for community water sources were not effective and water was found to be polluted based on testing. In cycle 3 , students will engage in local watertesting combined with community mapping to generate a shared community resource to identify clean water access points and sites of extreme pollution.

In the Photo Environment course, transdisciplinary learning took place through centering the real-world problem of water security, and inviting youth to engage with the topic through the lens of art (i.e., documentary photography), action (i.e., community awareness-raising), and various science (e.g., hydrology) and interdisciplinary (e.g., ecology) fields. Importantly, the course combined formal photography instruction (e.g., proper lighting techniques) and Western science (i.e., water testing kits) with participatory process. Photography and local action opportunities offered a way for youth to affectively connect with, capture, and communicate the importance of clean water access on their own terms and according to their own visions for community change towards a sustainable future.

An important difference between the US and Haiti case studies was the manner in which art-science integration was practiced. In the US, place-based "Science" activities were the primary platform for shared understanding and enthusiasm related to local sustainability challenges (i.e., climate change), whereas the arts (i.e., photography) became children's 'access route' to deeper connection with the science-framed subject matter. In Haiti, youths' photography was the primary platform for shared understanding and enthusiasm related to local sustainability challenges (i.e., water security), whereas science (e.g., water quality testing from local sources) became youths' 'access is mostly peripheral-hence the greater total surface area. The intermediary circles represent infinite iterations of art-science integration that blend the arts and sciences to a greater degree compared to the poles. ${ }^{a}$ Relative positioning of the US case study. ${ }^{b}$ Relative positioning of the Haiti case study

route' to deeper connection with the art-framed subject matter. In light of this key distinction, Fig. 2 presents a cursory spectrum of art-science integration, ranging from art- to science-centric integration. A strength of the methodological framework - and a benefit of facilitating art-science integration in divergent contexts-is exploring its versatility along this spectrum. The US case was closer, in practice, to the kinds of "STEAM-based" art-science arrangements that center science learning, whereas the Haiti case was closer to the kinds of arts-centered activism that have the capacity to mobilize the sciences in the service of social change. Across both cases, however, art-science integration was a platform for transdisciplinary learning, participatory process, and collaborative action for sustainability.

\section{Discussion}

This manuscript has discussed how art-science integration can be applied in ways that enable community members to envision and enact sustainable futures within local contexts. Case studies in the US and Haiti offer variations on art-science integration through an action-oriented methodological framework that combines 'top-down' as well as 'bottomup' processes to invite young people to learn about, connect with, and act on sustainability challenges in locally meaningful ways. The transformative potential of these alternative future-making pedagogies is discussed in the following sections, organized by the primary components of the framework on which each collaboration was based (Fig. 1): transdisciplinary learning, participatory process, and collaborative sustainability action. The collaborative research context within which case studies took place is also examined for its transformative potential, framed by key dimensions of transdisciplinary research. In pedagogical and research terms, to be transformative requires "a shift or a switch to a new way of being and seeing", not just for young people and 
'non-academics,' but for the researchers themselves (Wals 2011, p. 181; O'Sullivan 1999). From a sustainability perspective, realizing the transformative potential of alternative pedagogical and research practices means opening up new possibilities for building a sustainable future.

\section{Transdisciplinary learning: confronting complexity}

The methodological framework introduced in this manuscript 'begins' with transdisciplinary learning. A transdisciplinary approach to learning calls for centering the problem, rather than the discipline, in the process of acquiring knowledge. Moreover, transdisciplinary learning-like similar approaches (e.g., transformative learning; problem-based learning; Boström et al. 2018; Mezirow 1997; O'Sullivan 1999; Savery 2006)—considers learning as "more than merely knowledge based" (Wals 2011, p. 180). In the methodological framework, transdisciplinary learning is represented as a 'top-down' process because, in practice, this component served to provide young people with a broad awareness of sustainability challenges, immersing them in a 'big picture' view local environmental problems. Transdisciplinary learning was a way of introducing the problem (i.e., 'what is') and establishing a sense of shared understanding around present-day and projected future sustainability challenges. Doing so drew from research-based knowledge within relevant disciplines and became a starting point for young people's substantive participation in decision-making and action.

As indicated by the prefix 'trans', transdisciplinary pedagogies go beyond teaching according to specific disciplines (i.e., school subjects) and often embrace epistemological fluidity. The need for transdisciplinarity is tied to the need to address problems that are "real, complex, socially relevant ... [and], which ask for the integration of knowledge of science and society" (Scholz et al. 2016, p. 231). Most of these problems, such as climate change and clean water access, fall within the domain of sustainability. The case studies presented in this manuscript practiced transdisciplinarity both by 'starting from' local sustainability challenges (not disciplinary subjects) as well as by integrating the arts and sciences in the process of learning. Transdisciplinary learning has been advanced as a critical pathway towards envisioning sustainable futures with regard to both climate change and water access (e.g., Schneider and Rist 2014).

A challenge related to transdisciplinary learning in the present research was the way in which art-science integration was taken up by children and youth participants across case study contexts. In the US, children were at first confused about the photography component. Children across research sites asked questions like, "What should I photograph?" and seemed to perceive photovoice as a homework assignment that could receive a poor grade. Unfortunately, telling children that "there is no such thing as a wrong photograph" and that the content of photographs were to be "about what you think and how you feel" did not always clarify the task. By the third photovoice session, after seeing examples and experiencing photovoice discussions, children seemed to understand and enjoy the process more fully. In the Haitian context, there was less confusion about the content of photographs. From the outset, Haitian youth received guidance on how to take a good photograph, and they understood the task of photographing the beauty and challenges of their region. A possible explanation for this distinction is that the Haitian program started with the artistic process, whereas the US program started with handson science activities. It is possible that, in the US, children became epistemically 'stuck' in rationalist scientific thinking modes (i.e., focused on observation and evidence-gathering) as well as traditional expectations of school science (i.e., the right answers), which colored their interpretations of photovoice. Another possible explanation for this distinction is the divergent properties of the sustainability challenges addressed in each case study. Specifically, climate change takes place on a global scale and entails relatively less visible (atmospheric) processes, whereas water security challenges occur more locally and are more readily perceptible in the physical environment. Its traces are more visible and tangible. For photovoice process, this would require climate change-related photography to be more conceptual in nature-a higher-level task for young people. Given both of these distinctions, a recommendation for integrated art-science programming following this methodological framework and/or using variations of the photovoice method would be to emphasize, from the outset, photography as a mode of creative expression with the capacity to convey an idea, message, or emotion related to sustainability challenges. Doing so would also support learners' epistemological fluidity, in particular their sensibilities related to 'more-than-rational' ways of knowing (Colucci-Gray et al. 2013; Kagan 2011). Moreover, for climate change-related programming, it is important to employ place-based approaches that ground this complex, global phenomenon in local-scale manifestations of transformation, allowing learners to draw these linkages and 'see' climate change in their world.

Attempts to conceptualize transdisciplinarity-both in research and teaching - have often centered on a set of shared properties or attributes, rather than a single concrete definition. In outlining the "shared aims" of transdisciplinarity, Lawrence and Després (2004) assert that "transdisciplinarity tackles complexity in science and it challenges knowledge fragmentation" (p. 399). These features of transdisciplinarity are inherent not only in the pedagogical practices applied in the US and Haiti case studies, but also in the broader research environment within which each case study took place. In both case studies, notoriously complex 
environmental problems (i.e., climate change; water management) became the 'subject' of each collaboration, and the learning process drew from a broad array of epistemological and disciplinary lenses. Moreover, this research brought together researchers and educators with backgrounds in psychology, anthropology, ecology, and the arts. By transcending disciplinary norms and focusing on problems, transdisciplinary teams are:

... able to explore the limits and blind spots of their different disciplinary epistemologies, with each discipline undergoing modification to take on insights from the other fields. In this way, they create new knowledge, tools, and perspectives that differ from the foundation and approach offered by any one discipline. (Skorton and Bear 2018, p. 69).

The transformative potential of these modes lies not only in transcending boundaries of epistemology (i.e., art-science integration) and discipline (i.e., research collaboration), but also in traversing borders of campus (i.e., university-community partnership), and nation (i.e., international collaboration).

\section{Participatory process: attending to context}

In the methodological framework introduced in this manuscript, transdisciplinary learning is combined with participatory process. By inviting the full participation of all involved, participatory approaches seek to break down established hierarchies in traditional approaches to teaching and research. Put differently, participatory modes blend the boundaries between the categories 'researcher' and 'the researched,' 'educator' and 'the educated' by positioning everyone involved as a capable contributor to the process of acquiring and generating knowledge. In the methodological framework, the participatory approach is represented as a 'bottom-up' process because it enabled the full and active participation of young people in making sense of sustainability challenges on their own terms in local settings, rather than relying solely on the unidirectional 'transmission' of research-based knowledge (Sterling 2001; Wals 2011). Participatory process, through digital photography, became a way to invite children and youth to make sense of complex problems from their own position and point of view, serving to anchor abstract sustainability concepts in tangible objects, concrete observations, and real-world relationships (Trott 2019b). Moreover, participatory process urged young people to draw on their own knowledge and life experiences to make cognitive as well as affective connections to sustainability challenges as well as to imagine alternatives to the nonsustainable status quo (i.e., 'what if?') and then act on those visions (Trott 2019a). Whereas transdisciplinary learning became a platform for youths' shared understanding around the problem, participatory process became a platform for shared meaning-making around potential solutions.

The participatory component of each case study was guided by photovoice, which is a participatory research method. As occurred in each case study, photovoice exhibitions offered a way to showcase community strengths and concerns, while advocating for social and policy change. Across case studies, photography was engaged both as a learning tool for sustainability as well as an artform-a way to rethink present realities as well as envision and enact alternatives (Trott 2019a). From a pedagogical perspective, photography served as a bridge between epistemologies-bringing together research- and experiencebased knowledge, projected and imagined futures, science and art. From a research standpoint, visual methods (e.g., photovoice, hand drawings) offer the added benefit of cultivating within young people a sense of agency in the research process (Johnson et al. 2012). In the present research, photography was a translational means through which children were able to channel and communicate their deepest concerns and greatest hopes for the future. Both case studies engaged with the transformative potential of the arts to challenge unsustainable norms and demand social change.

A notable challenge limiting the social change potential of art-science integration across case studies is that neither was genuinely participatory from the outset. A key component of fully participatory engagements is that they allow for the process of problem identification to lie primarily with community partners, in this case, children and youth. Instead, in each case study, we-as researchers-defined the problem (i.e., sustainability challenge) in advance. In some ways, this is a classic challenge of any university-community partnership practicing participatory modes and requiring institutional review board approval and/or funding. That is, to write the proposal, a description of the project's aims and objectives-usually including a literature review and statement of the project's main contributions-is required in advance. On the one hand, the need for a problem definition at the outset of a project is consistent with transdisciplinary learning (Quigley et al. 2017). On the other, defining the problem in advance limits the full participation of community partners (Kindon et al. 2007). In both case studies, however, a 'middle way' was to define the broad sustainability challenge (e.g., water; climate change) in advance, but not the collaborative action projects designed and implemented by the youth participants. Rather, we emphasized in proposals the need for community engagement in addressing sustainability challenges at the local level, and the ways in which participatory research could yield increasingly meaningful outputs yet to be determined. Then, in both settings, specific, youth-defined facets of the problem (e.g., lack of community awareness; the need for new policies) became a platform for 
youth-led action-allowing them a sense of ownership of the problem and its solutions in their communities.

Participatory process, as practiced in the present case studies through photovoice, also maps onto the shared aims of transdisciplinary research advanced by Lawrence and Després (2004). According to them, a second key dimension of transdisciplinary research is that it "accepts local contexts and uncertainty; it is a context-specific negotiation of knowledge" (p. 399). This feature of transdisciplinarity is again apparent both at the level of each case study as well as in the broader research context. First, participatory process is, by definition, a way of attending to local context. During each case study, children and youth brought their own knowledge, values, and life experience into conversation with larger sustainability concepts and principles. In the broader research context, the way art-science integration took shape in the US and Haiti was in many ways an outcome of context-specificity. In the US - specifically BGCcontext, integrated art-science programming meant infusing the arts into STEM, and framing sustainability challenges primarily in science terms. In Haiti-and specifically the community arts organization, integration meant infusing STEM into art-focused programming and conveying sustainability challenges primarily through the arts. In some ways, the nature of art-science integration practiced in each setting was grounded in the broader regional context. Whereas the US region is widely known for its climate science, the Haitian region is widely known for its arts and culture. What this meant for the practice of art-science integration in each setting was that, in the US, children explained climate change through the stories of their photographs, whereas young Haitians told the stories of their photographs with reference to the science. Across settings, photography became a translational medium for young people to communicate their knowledge, feelings, and hopes for the future (Star and Griesemer 1989). Importantly, children's photography prompted social change action.

\section{Collaborative action: generating sustainability}

The final component in the methodological framework presented in this manuscript is collaborative action. In the overlapping space at the center of the figure, action represents the culmination of transdisciplinary learning (i.e., contemplating 'what is') and participatory process (i.e., imagining 'what if?'). Across case studies, this combination of 'topdown' and 'bottom-up' processes offered children and youth a firm foundation upon which to collaboratively act on their knowledge, values, and concerns to attempt to change the situation for the better. In the US, this process took the shape of planting trees and establishing local gardens as well as holding public events to advocate with adults and policymakers around the importance of climate action. In Haiti, young people alerted local residents about threats to their local water supply and held public events to raise awareness, communicate their concerns, and advocate for change. In these ways, both case studies facilitated critical engagement with present realities as a way to think about, imagine, advocate for, and enact alternative futures. By combining transdisciplinary learning, participatory process, and collaborative action, this methodological framework activates all components of the "Head, Hands, and Heart" model of transformative sustainability learning (Sipos et al. 2008). Specifically, the integrated art-science pedagogies exhibited in each case study - despite some unnecessary distinctions and obvious domain overlaps-combined youths' cognitive engagement (i.e., head) through transdisciplinary learning, with affective enablement (i.e., heart) through participatory process, and resulted in behavioral enactment for sustainability (i.e., hands) through youth-led projects (Sipos et al. 2008; Trott 2019a). In the context of sustainability, taking collaborative action can be a way for young people to develop a sense of agency in the face of seemingly insurmountable challenges, which is critical to their sustained interest and engagement (Ojala 2016; Riemer et al. 2014; Trott 2019a, b).

In this methodological framework, collaborative action was an outcome of participatory processes grounded in the tradition of action research. Action research traditions, including PAR and likeminded variations (e.g., community-based participatory action research; transdisciplinary action research; critical utopian action research; systemic action research), are simultaneously dedicated to research and social change (Gayá and Brydon-Miller 2017; Kindon et al. 2007; Stokols 2006). For example, prefigurative action research-an orientation that was influential in both case studies - has been described as an approach to research that aims to study something in order to change it (Kagan and Burton 2000). Across case studies, transdisciplinary learning and participatory process were intended to form a platform for youth action. Specifically, through art-science integration, educational activities and digital photography became the medium through which young people developed shared understanding around local sustainability challenges. A third characteristic of transdisciplinarity, offered by Lawrence and Després (2004), is "intercommunicative action", which refers to a process of negotiation and "making sense together" (Klein 2004, p. 521) in order to achieve mutual understanding. Achieving this form of intersubjectivity is not only the basis for further action in transdisciplinary research but is itself a form of action necessary to addressing sustainability challenges. Art-science integration, in both case studies, became the foundation upon which youth-led collaborative action plans were constructed.

A challenge related to art-science integration for collaborative sustainability action, across case studies, was 
that photography can sometimes feel limited to capturing present-day realities rather than facilitating children's abilities to envision alternative futures. Indeed, the tradition of documentary photography is grounded in capturing real-life settings and situations as they occur. Nevertheless, documentary photography is often a means to spark critical dialogue and prompt social change and, hence, is tied to the creation of alternative futures. Because photovoice is increasingly used in action-oriented environmental and sustainability education settings, some scholars have noted this limitation and are modifying the method towards 'opening up' the ways in which children may express their democratic imaginations (Derr and Simons 2019). For example, CreativeVoice-which expands modes of artistic expression to include drawings, paintings, film, etc.-better allows participants to "move beyond capturing present-day realities" and make connections to the past and to desired futures (Rivera Lopez et al. 2018, p. 1778). We agree that additional artforms would indeed expand the forms of connection-making and visioning available to youth participants, while standing by more traditional forms of photovoice process to facilitate critical engagement with present realities and prompt collaborative action for social change in local settings (Wang et al. 2004). Expanding the artforms available to learners may also assist in overcoming challenges related to visually 'capturing' climate change-related phenomena through photography, as occurred in the US case study. Doing so may also help with engaging a younger audience who may struggle with photography — but thrive with drawing —as a way to communicate their thoughts, feelings, and hopes for the future.

The fourth and final dimension of transdisciplinarity noted by Lawrence and Després (2004) is an action orientation in research. According to them, "transdisciplinary contributions frequently deal with real-world topics and generate knowledge that not only address societal problems but also contribute to their solution" (p. 399). Implied in this crucial dimension is that, in transdisciplinarity, there is a blurring of boundaries, not only between disciplines, but also "between theoretical development and professional practice." This action orientation is a critical feature not only in each case study context, but in the context of sustainability research more broadly. In recent years, sustainability scholars have been called upon to break from traditional modes of research that are "descriptive-analytic" (i.e., problem-focused) and begin to practice a "solution-oriented approach" that gives greater attention to identifying viable pathways to a sustainable future (Wiek et al. 2012, p. 6). In theorizing transformational sustainability research, Wiek et al. (2012) anticipate a new role for scientists in which:

...scientists no longer "only" analyze sustainability issues, but, rather, need to immerse themselves into decision processes that are embedded in societal transition processes and build socially robust knowledgewith necessary changes in research modes, incentive structures, and reward systems. (p. 7)

As implied above, engaging with multiple stakeholders is a necessity in sustainability research and in addressing sustainability challenges more generally. The deliberate inclusion of non-scientists (e.g., young people) as well as "non-strictly scientific forms of knowledge" (e.g., the arts) have been proposed as a "criterion for quality in sustainability science" (Colucci-Gray et al. 2013, p. 136; Ziegler and Ott 2011). Across case studies, children and youth acquired, transmitted, and generated knowledge about local sustainability challenges, acting as change agents for the sustainable transformation of their communities. In these ways, the present research prefigures a sustainable future, while acting towards it - through art-science integration - in collaboration with young people.

\section{Conclusions}

In the spirit of transdisciplinarity, this manuscript has taken global sustainability crises as its central issues, and-towards building a sustainable future through actionoriented research — has mobilized numerous disciplinary approaches to identify viable paths forward. It has traced new linkages, both in theory and in practice, between the already-interdisciplinary literatures of art-science integration, alternative future-making pedagogies, and youth-led sustainability action. The action-oriented methodological framework introduced in this manuscript takes seriously the role of young people in learning about, connecting with, and acting on sustainability challenges where they live. Case studies make clear that young people are not only capable of, but passionate about protecting their future through social and environmental action-and art-science integration is a promising pathway towards facilitating their meaningful participation.

Open Access This article is licensed under a Creative Commons Attribution 4.0 International License, which permits use, sharing, adaptation, distribution and reproduction in any medium or format, as long as you give appropriate credit to the original author(s) and the source, provide a link to the Creative Commons licence, and indicate if changes were made. The images or other third party material in this article are included in the article's Creative Commons licence, unless indicated otherwise in a credit line to the material. If material is not included in the article's Creative Commons licence and your intended use is not permitted by statutory regulation or exceeds the permitted use, you will need to obtain permission directly from the copyright holder. To view a copy of this licence, visit http://creativecommons.org/licenses/by/4.0/. 


\section{References}

Ballantyne R, Connell S, Fien J (1998) Students as catalysts of environmental change: a framework for researching intergenerational influence through environmental education. Environ Educ Res 4(3):285-298. https://doi.org/10.1080/13504620600942972

BGC (2019) Boys and Girls Clubs of America 2018 annual report. https://www.bgca.org/ Accessed 15 Jun 2019

Birdsall S (2013) Reconstructing the relationship between science and education for sustainability: a proposed framework of learning. Int J Environ Sci Educ 8(3):451-478. https://doi.org/10.12973/ ijese.2013.214a

Boström M, Andersson E, Berg M, Gustafsson K, Gustavsson E, Hysing E, Lidskog R, Löfmarck E, Ojala M, Olsson J, Singleton B (2018) Conditions for transformative learning for sustainable development: a theoretical review and approach. Sustain 10(12):4479. https://doi.org/10.3390/su10124479

Bourn D, Hunt F, Bamber P (2017) A review of Education for Sustainable Development and Global Citizenship Education in teacher education. Paper commissioned for the 2017/8 Global Education Monitoring Report. https://unesdoc.unesco.org/in/rest/annot ationSVC/DownloadWatermarkedAttachment/attach_impor t_40e98442-c551-4ee6-a69c-4e0557f2d548?_=259566eng.pdf. Accessed 15 Jun 2019

Bush C, Cook KL (2019) Structuring STEAM inquiries: lessons learned from practice. In: Khine MS, Areepattamannil S (eds) STEAM education: theory and practice. Springer Nature, Switzerland, pp 19-24. https://doi.org/10.1007/978-3-030-04003-1_2

Colucci-Gray L, Perazzone A, Dodman M, Camino E (2013) Science education for sustainability, epistemological reflections and educational practices: from natural sciences to trans-disciplinarity. Cult Stud Sci Educ 8(1):127-183. https://doi.org/10.10007/s1142 2-012-9405-3

Cook JW (ed) (2019). Sustainability, human well-being, and the future of education. Springer Nature, Cham. https://doi. org/10.1007/978-3-319-78580-6

Cook K, Quigley CF (2013) Connecting to our community: utilizing photovoice as a pedagogical tool to connect college students to science. Int J Environ Sci Educ 8(2):339-357. https://doi. org/10.12973/ijese.2013.205a

Cook K (2015) Grappling with wicked problems: exploring photovoice as a decolonizing methodology in science education. Cult Stud Sci Educ 10(3):581-592. https://doi.org/10.1007/s1142 2-014-9613-0

Corner A, Roberts O, Chiari S, Völler S, Mayrhuber ES, Mandl S, Monson K (2015) How do young people engage with climate change? The role of knowledge, values, message framing, and trusted communicators. Wiley Interdisc Rev Clim Change 6(5):523-534. https://doi.org/10.1002/wcc.353

Cutter-Mackenzie A, Rousell D (2019) Education for what? Shaping the field of climate change education with children and young people as co-researchers. Children's Geogr 17(1):90-104. https ://doi.org/10.1080/14733285.2018.1467556

Cutter-Mackenzie-Knowles A, Rousell D (2018) The mesh of playing, theorizing, and researching in the reality of climate change: creating the co-research playspace. In: Cutter-MackenzieKnowles A, Malone K, Barratt Hacking E (eds) Research handbook on childhood nature: assemblages of childhood and nature research. Springer Nature, Switzerland, pp 1-25. https://doi. org/10.1007/978-3-319-51949-4_14-1

Davis JM (2015) Young children and the environment: early education for sustainability, 2nd edn. Cambridge University Press, Port Melbourne

Derr V, Simons J (2019) A review of photovoice applications in environment, sustainability, and conservation contexts: is the method maintaining its emancipatory intents? Environ Educ Res. https:// doi.org/10.1080/13504622.2019.1693511

ECVMAS (2012) Rapport Enquête sur les Conditions de Vie des Ménages Après le Séisme Haiti 2012. https://ecvmashaiti2012 .e-monsite.com/pages/presentation.html. Accessed 15 Jun 2019

Facer K (2019) Storytelling in troubled times: what is the role for educators in the deep crises of the 21st century? Literacy 53(1):3-13. https://doi.org/10.1111/lit.12176

Fisher SR (2016) Life trajectories of youth committing to climate activism. Environ Educ Res 22(2):229-247. https://doi. org/10.1080/13504622.2015.1007337

Fischer J, Manning AD, Steffen W, Rose DB, Daniell K, Felton A, Garnett S, Gilna B, Heinsohn R, Lindenmayer DB, MacDonald B (2007) Mind the sustainability gap. Trends Ecol Evol 22(12):621-624. https://doi.org/10.1016/j.tree.2007.08.016

Foster-Fishman P, Nowell B, Deacon Z, Nievar MA, McCann P (2005) Using methods that matter: the impact of reflection, dialogue, and voice. Am J Community Psych 36(3-4):275-291. https:// doi.org/10.1007/s10464-005-8626-y

Freire P (1972) Pedagogy of the oppressed. Penguin, Harmondsworth

Funtowicz SO, Ravetz JR (1993) Science for the post-normal age. Futures 25(7):739-755. https://doi.org/10.1016/00163287(93)90022-L

Gayá P, Brydon-Miller M (2017) Carpe the academy: dismantling higher education and prefiguring critical utopias through action research. Futures 94:34-44. https://doi.org/10.1016/j.futur es.2016.10.005

Ghanbari S (2015) Learning across disciplines: a collective case study of two university programs that integrate the arts with STEM. Int J Educ Arts 16(7):1-21

Håkansson M, Kronlid DO, Östman L (2019) Searching for the political dimension in education for sustainable development: socially critical, social learning and radical democratic approaches. Environ Educ Res 25(1):6-32. https://doi.org/10.1080/13504 622.2017.1408056

Hall BL (1981) Participatory research, popular knowledge and power: a personal reflection. Convergence 14(3):6-19

Hart P, Nolan K (1999) A critical analysis of research in environmental education. Stud Sci Educ 34:1-69. https://doi.org/10.1080/03057 269908560148

Haynes K, Tanner TM (2015) Empowering young people and strengthening resilience: youth-centred participatory video as a tool for climate change adaptation and disaster risk reduction. Children's Geogr 13(3):357-371. https://doi.org/10.1080/14733 285.2013.848599

Hayward B (2012) Children, citizenship and environment: nurturing a democratic imagination in a changing world. Routledge, New York

Heras M, Tàbara JD (2014) Let's play transformations! Performative methods for sustainability. Sustain Sci 9(3):379-398. https://doi. org/10.1007/s11625-014-0245-9

Heras M, Tàbara JD, Meza A (2016) Performing biospheric futures with younger generations: a case in the MAB Reserve of La Sepultura. Mexico Ecol Soc 21(2):14. https://doi.org/10.5751/ ES-08317-210214

Herro D, Quigley C, Cian H (2019) The challenges of STEAM instruction: lessons from the field. Action Teacher Educ 41(2):172-190. https://doi.org/10.1080/01626620.2018.1551159

Hetland L (2013) Studio thinking 2: the real benefits of visual arts education. Columbia University Teachers College Press, New York

Hicks D (2014) Educating for hope in troubled times: climate change and the transition to a post-carbon future. Trentham Books Limited, Staffordshire

Hodson D (2003) Time for action: science education for an alternative future. Int J Sci Educ 25(6):645-670. https://doi. org/10.1080/09500690305021 
Hodson D (2011) Looking to the future: building a curriculum for social activism. Sense Publications, Rotterdam

Holfelder AK (2019) Towards a sustainable future with education? Sustain Sci. https://doi.org/10.1007/s11625-019-00682-z

IBE-UNESCO (2019) Transdisciplinary approach. https://www.ibe. unesco.org/en/glossary-curriculum-terminology/t/transdisci plinary-approach

Jackson T (2017) Prosperity without growth. Foundations for the economy of tomorrow, 2nd edn. Routledge, New York

Jenkins EW (1994) Public understanding of science and science education for action. J Curric Stud 26(6):601-611. https://doi. org/10.1080/0022027940260602

Jensen BB, Schnack K (2006) The action competence approach in environmental education. Environ Educ Res 3(2):163-178. https:// doi.org/10.1080/13504620600943053

Johnson LR, Johnson-Pynn JS, Lugumya DL, Kityo R, Drescher CF (2013) Cultivating youth's capacity to address climate change in Uganda. Int Perspect Psych Res Pract Consult 2(1):29-44. https ://doi.org/10.1037/a0031053

Johnson GA, Pfister AE, Vindrola-Padros C (2012) Drawings, photos, and performances: using visual methods with children. Visual Anthro Rev 28(2):164-178

Jorgenson SN, Stephens JC, White B (2019) Environmental education in transition: a critical review of recent research on climate change and energy education. J Environ Educ 50(3):160-171. https://doi.org/10.1080/00958964.2019.1604478

Kagan S (2008) Sustainability: a new frontier for the arts and cultures. Vas Verlag Fur Akademisch, Frankfurt

Kagan S (2011) Art and sustainability: connecting patterns for a culture of complexity. Transaction Publishers, Piscataway

Kagan C, Burton M (2000) Prefigurative action research: an alternative basis for critical psychology. Ann Rev Crit Psych 2(73-87).

Kaufmann N, Sanders C, Wortmann J (2019) Building new foundations: the future of education from a degrowth perspective. Sustain Sci. https://doi.org/10.1007/s11625-019-00699-4

Kelsey E, Armstrong C (2012) Finding hope in a world of environmental catastrophe. In: Wals AE, Corcoran PB (eds) Learning for sustainability in times of accelerating change. Wageningen Academic Publishers, Wageningen, pp 187-200

Kenis A, Mathijs E (2014) Climate change and post-politics: repoliticizing the present by imagining the future? Geoforum 52:148-156

Kindon S, Pain R, Kesby M (eds) (2007) Participatory action research approaches and methods: connecting people, participation and place. Routledge, Abington

Klein JT (2004) Prospects for transdisciplinarity. Futures 36(4):515-526

Kuiper K (2016) The arts. https://www.britannica.com/topic/the-arts

Land MH (2013) Full STEAM ahead: the benefits of integrating the arts into STEM. Procedia Comp Sci 20:547-552. https://doi. org/10.1016/j.procs.2013.09.317

Lawrence RJ, Després C (2004) Futures of transdisciplinarity. Futures 4(36):397-405

Lester BT, Ma L, Lee O, Lambert J (2006) Social activism in elementary science education: a science, technology, and society approach to teach global warming. Int J Sci Educ 28(4):315-339. https://doi.org/10.1080/09500690500240100

Liao C (2019) Creating a STEAM map: a content analysis of visual art practices in STEAM education. In: Khine MS, Areepattamannil $\mathrm{S}$ (eds) STEAM education: theory and practice. Springer, Switzerland, pp 37-55. https://doi.org/10.1007/978-3-030-04003-1_3

Maeda J (2013) STEM + Art=STEAM. STEAM J 1(1):34. https://doi. org/10.5642/steam.201301.34

Malone K (2013) "The future lies in our hands": children as researchers and environmental change agents in designing a child-friendly neighbourhood. Local Environ 18(3):372-395. https://doi. org/10.1080/13549839.2012.719020

Marmon M (2019) The emergence of creativity in STEM: fostering an alternative approach for Science, Technology, Engineering, and Mathematics instruction through the use of the Arts. In: Khine MS, Areepattamannil S (eds) STEAM education: theory and practice. Springer, Switzerland, pp 101-115. https://doi. org/10.1007/978-3-030-04003-1_6

Meadows DL, Randers J (1992) Beyond the limits: global collapse or a sustainable future. Earthscan Publications Ltd., London

Merriam-Webster (2019) Integrate. https://www.merriam-webster.com/ dictionary/integrate

Mezirow J (1997) Transformative learning: theory to practice. New Direct Adult Continuing Educ 1997(74):5-12

Mitra D, Serriere S, Kirshner B (2014) Youth participation in US contexts: student voice without a national mandate. Child Soc 28(4):292-304. https://doi.org/10.1111/chso.12005

Monroe MC, Plate RR, Oxarart A, Bowers A, Chaves WA (2017) Identifying effective climate change education strategies: a systematic review of the research. Environ Educ Res 12:1-22. https://doi. org/10.1080/13504622.2017.1360842

National Foundation on the Arts and the Humanities Act (1965). https ://www.law.cornell.edu/uscode/text/20/951. Accessed 28 Nov 2019

National Science Foundation (2015) Revisiting the STEM workforce: a companion to science and engineering indicators 2014. https ://www.nsf.gov/pubs/2015/nsb201510/nsb201510.pdf. Accessed 23 Jun 2019 (28 Nov. 2019)

NSTA (2019) National science teaching association: about the next generation science standards. https://ngss.nsta.org/About.aspx. Accessed 15 Jun 2019

O'Sullivan E (1999) Transformative learning: educational vision for the twenty first century. Zed Books, London

Ojala M (2016) Preparing children for the emotional challenges of climate change: a review of the research. In: Winograd K (ed) Education in times of environmental crises: teaching children to be agents of change. Routledge, New York, pp 210-218

Osnes B (2017) Performance for resilience: engaging youth on energy and climate through music, movement, and theatre. PalgraveMacmillan, New York

Palmer JA (1998) Environmental education in the 21st century: theory, practice, progress and promise. Routledge, London

Percy-Smith B, Burns D (2013) Exploring the role of children and young people as agents of change in sustainable community development. Local Environ 18(3):323-339. https://doi. org/10.1080/13549839.2012.729565

Phelan AM (2004) Rationalism, complexity science and curriculum: a cautionary tale. Complicity Int J Complexity Educ 1(1):9-17. https://doi.org/10.29173/cmplct8712

Pipere A (2016) Envisioning complexity: towards a new conceptualization of educational research for sustainability. Discourse Comm Sustain Educ 7(2):68-91. https://doi.org/10.1515/ dcse-2016-0017

Psycharis S (2018) STEAM in education: a literature review on the role of computational thinking, engineering epistemology and computational science. Computational STEAM pedagogy (CSP). Sci Cult 4(2):51-72. https://doi.org/10.5281/zenodo.1214565

Qvortrup J (2009) Are children human beings or human becomings? A critical assessment of outcome thinking. Rivista Internazionale di Scienze Sociali 3-4:631-653

Quigley CF, Herro D, Baker A (2019) Moving toward transdisciplinary instruction: a longitudinal examination of STEAM teaching practices. In: Khine MS, Areepattamannil S (eds) STEAM education: theory and practice. Springer Nature, Switzerland, pp 143-164. https://doi.org/10.1007/978-3-030-04003-1_8 
Quigley CF, Herro D, Jamil FM (2017) Developing a conceptual model of STEAM teaching practices. School Sci Math 117(1-2):1-2. https://doi.org/10.1111/ssm.12201

Rasmussen K, Smidt S (2003) Children in the neighborhood. In: Christensen P, O'Brien M (eds) Children in the city: home, neighbourhood and community. Routledge, London, pp 82-100

Rathwell KJ, Armitage D (2016) Art and artistic processes bridge knowledge systems about social-ecological change: an empirical examination with Inuit artists from Nunavut, Canada. Ecol Soc 21(2):21. https://doi.org/10.5751/ES-08369-210221

Riemer M, Lynes J, Hickman G (2014) A model for developing and assessing youth-based environmental engagement programmes. Environ Educ Res 20(4):552-574. https://doi.org/10.1080/13504 622.2013.812721

Rittel HW, Webber MM (1973) Dilemmas in a general theory of planning. Policy Sci 4(2):155-169

Rivera Lopez F, Wickson F, Hausner V (2018) Finding CreativeVoice: applying arts-based research in the context of biodiversity conservation. Sustain 10:1778. https://doi.org/10.3390/su10061778

Rooney-Varga JN, Brisk AA, Adams E, Shuldman M, Rath K (2014) Student media production to meet challenges in climate change science education. J Geosci Educ 62(4):598-608. https://doi. org/10.5408/13-050.1

Roth WM, Lee S (2004) Science education as/for participation in the community. Sci Educ 88(2):263-291

Roy SG, de Souza SP, McGreavy B, Druschke CG, Hart DD, Gardner K (2019) Evaluating core competencies and learning outcomes for training the next generation of sustainability researchers. Sustain Sci. https://doi.org/10.1007/s11625-019-00707-7

Sadler TD (2009) Situated learning in science education: socio-scientific issues as contexts for practice. Stud Sci Educ 45(1):1-42. https://doi.org/10.1080/03057260802681839

Savery JR (2006) Overview of problem-based learning: definition and distinctions. Interdiscip J Problem Based Learn 1(1):9-20. https ://doi.org/10.7771/1541-5015.1002

Schneider F, Rist S (2014) Envisioning sustainable water futures in a transdisciplinary learning process: combining normative, explorative, and participatory scenario approaches. Sustain Sci 9(4):463-481

Scholz RW, Lang DJ, Wiek A, Walter AI, Stauffacher M (2016) Transdisciplinary case studies as a means of sustainability learning: historical framework and theory. Int J Sustain High Educ 7(3):226-251

Schreiner C, Henriksen EK, Kirkeby Hansen PJ (2005) Climate education: empowering today's youth to meet tomorrow's challenges. Studies Sci Educ 41(1):3-49

Singleton J (2015) Head, heart and hands model for transformative learning: place as context for changing sustainability values. J Sustain Educ 9:1-16

Sipos Y, Battisti B, Grimm K (2008) Achieving transformative sustainability learning: engaging head, hands and heart. Int J Sustain High Educ 9(1):68-86. https://doi.org/10.1108/1467637081 0842193

Skorton D, Bear A (eds) (2018) The integration of the humanities, and arts with sciences, engineering and medicine in higher education: branches from the same tree. The National Academies Press, Washington. https://doi.org/10.17226/24988

Sterling S (2001) Sustainable education: re-visioning learning and social change. Books, Totnes

Sterling S (2004) An analysis of the development of sustainability education internationally: evolution, interpretation, and transformative potential. In: Blewitt J, Cullingford C (eds) The sustainability curriculum: the challenge for higher education. Earthscan, London, pp 43-62

Stokols D (2006) Toward a science of transdisciplinary action research. Am J Commun Psych 38(1-2):79-93
Stratford E, Low N (2015) Young islanders, the meteorological imagination, and the art of geopolitical engagement. Children's Geogr 13(2): $164-180$

Tate (2019) Documentary photography. https://www.tate.org.uk/art/ art-terms/d/documentary-photography

Taylor E, Taylor PC (2017) Breaking down enlightenment silos: from STEM to ST2EAM education, and beyond. In: Bryan L, Tobin K (eds) 13 questions: reframing education's conversation: science. Peter Lang, New York, pp 455-472

Toomey AH, Markusson N, Adams E, Brockett B (2015) Inter-and transdisciplinary research: a critical perspective. https://susta inabledevelopment.un.org/content/documents/612558-Inter-\%20 and\%20Trans-disciplinary\%20Research\%20-\%20A\%20Critical \%20Perspective.pdf. Accessed 15 Jun 2019

Trott CD (2017) Engaging key stakeholders in climate change: a community-based project for youth-led participatory climate action. Colorado State University Libraries. https://mountainscholar.org/ handle/10217/181349

Trott CD (2019a) Reshaping our world: collaborating with children for community-based climate change action. Action Res 17(1):42-62

Trott CD (2019b) Children's constructive climate change engagement: empowering awareness, agency, and action. Environ Educ Res. https://doi.org/10.1080/13504622.2019.1675594

UNESCO (2019) What is education for sustainable development? https ://en.unesco.org/themes/education-sustainable-development/ what-is-esd. Accessed 15 Jun 2019

van Kerkhoff L, Lebel L (2006) Linking knowledge and action for sustainable development. Annu Rev Environ Resour 31:445-477. https://doi.org/10.1146/annurev.energy.31.102405.170850

Wals AE (2011) Learning our way to sustainability. J Ed Sustain Dev 5(2):177-186. https://doi.org/10.1177/097340821100500208

Wang CC, Morrel-Samuels S, Hutchison PM, Bell L, Pestronk RM (2004) Flint photovoice: community building among youths, adults, and policymakers. Am J Public Health 94(6):911-913

Weinberg AE, Sample McMeeking LB (2017) Toward meaningful interdisciplinary education: high school teachers' views of mathematics and science integration. School Sci Math 117(5):204213. https://doi.org/10.1111/ssm.12224

Wiek A, Ness B, Schweizer-Ries P, Brand FS, Farioli F (2012) From complex systems analysis to transformational change: a comparative appraisal of sustainability science projects. Sustain Sci 7(1):5-24. https://doi.org/10.1007/s11625-011-0148-y

Wilson EO (1998) Back from the Chaos. https://www.theatlantic.com/ magazine/archive/1998/03/back-from-chaos/308700/. Accessed 10 Dec 2019

World Commission on Environment and Development (1987) Our common future. Oxford University Press, Oxford

Wyness M, Harrison L, Buchanan I (2004) Childhood, politics and ambiguity: towards an agenda for children's political inclusion. Soc 38(1):81-99. https://doi.org/10.1177/0038038504039362

Yarime M, Trencher G, Mino T et al (2012) Establishing sustainability science in higher education institutions: towards an integration of academic development, institutionalization, and stakeholder collaborations. Sustain Sci 7:101-113. https://doi.org/10.1007/ s11625-012-0157-5

Ziegler R, Ott K (2011) The quality of sustainability science: a philosophical perspective. Sustain Sci Practice Policy 7(1):31-44. https://doi.org/10.1080/15487733.2011.11908063

Publisher's Note Springer Nature remains neutral with regard to jurisdictional claims in published maps and institutional affiliations. 